\title{
Assistance and Education of Community Perception Related to Covid- 19 Vaccine in Benteng Kelurahan, Ciamis District, Ciamis Regency
}

\author{
Lilis Lismayantia), Rudi Kurniawan, and Yanti Srinayanti \\ STIKes Muhammadiyah Ciamis, Ciamis, Indonesia \\ a)Corresponding author: lilislismayanti85@gmail.com
}

\begin{abstract}
At the beginning of 2020, the whole world was shocked by the outbreak of a new virus, namely the corona virus which was suspected to be a new type of SARS COV-2. The Indonesian government has made various efforts to overcome the COVID-19 pandemic, including plans to provide a Covid-19 vaccine, but the public's main concern is on the safety and effectiveness of the vaccine, and whether the vaccine will be considered halal. Therefore, according to the review above, the researcher wants to carry out community service related to the perception of the covid-19 vaccine in the Benteng Village in order to have access to accurate information about the safety and effectiveness of the vaccine. This community service method is counseling and assistance to partners. The results of the activity showed that the community was very enthusiastic about participating in the Covid-19 vaccine counseling according to an Islamic view which contained information about the vaccine program, safety, halalness and effectiveness of the Covid-19 vaccine and actively participated in discussions and Q\&A with companions. In conclusion, the Covid-19 Vaccine health education can increase public knowledge about the Covid-19 vaccine according to the Islamic view
\end{abstract}

Keywords : Covid-19, perception, vaccine

\section{INTRODUCTION}

At the beginning of 2020 the whole world was shocked by the outbreak of a new virus, namely the corona virus which was suspected to be a new type of SARS COV-2 (Setiawan, Khairunnisa, \& Oktavia, 2021). Corona virus is a viral infection that started in China at the end of 2019 and is currently growing rapidly throughout the world (Nishiura et al, 2020). The effects of covid 19 have an impact with very high consequences, such as health, economic, and social (Wilder-Smith \& Freedman, 2020). In the health system, it has an impact on the increasing number of patients with health problems and other neglected diseases and medical personnel who are overwhelmed with the increasing number of COVID-19 patients.

In the economic order, the impact on the production of goods is hampered, causing many workers to be sent home (Suppawittaya, Yiemphat, \& Yasri, 2020). And for social this case has an impact on undue pressure among the population that distances social interaction with peers and even family members due to the implementation of social distancing. Even more sadly, not a few family members dare to dispose of other family members suspected of being infected with the infection, one of which is a health worker (Haleem et al, 2020).

The Indonesian government has made various efforts to overcome the COVID-19 pandemic, including plans to provide a COVID-19 vaccine (Srinayanti, Malik, \& Sandi, 2021). As part of this effort, the author has conducted a survey related to the views, perceptions, and concerns of the public regarding the COVID-19 vaccination. The survey took place from 22 to 24 February 2021 on 285 family cards (KK) in the Benteng village neighborhood.

$95 \%$ of respondents said that they had heard about the COVID-19 vaccine and about $3 \%$ were willing to accept it while another $97 \%$ refused to be vaccinated against COVID-19 with different levels of acceptance based on province, economic status, religion/belief, and educational status (Firmansyah et al., 2021). Across the country, respondents who were better informed about vaccines were more likely to receive them, and those with health insurance were also more likely 
to receive the COVID-19 vaccine. Among respondents who refused, their main concern was on the safety and effectiveness of the vaccine, and whether the vaccine would be considered halal.

According to the Islamic view, the act of following the vaccination if it is intended to carry out Allah's commands, such as protecting oneself and the environment from the plague, then becomes worship. Rasulullah SAW said which means "whoever relieves the difficulties of a believer from the difficulties of the world, surely Allah will relieve his difficulties from various difficulties on the Day of Resurrection" (HR Bukhari Muslim) (Hidayat, 2021).

Therefore, according to the review above, the researcher wants to carry out community service related to the perception of the covid-19 vaccine in the Benteng Village in order to have access to accurate information about the safety and effectiveness of the vaccine.

\section{METHOD}

This community service will be held on Sunday, February 20, 2021, at the Baitur-Rohman Mosque in the Bangunsari Environment, Benteng Village, Ciamis District, Ciamis Regency. Partners in this activity are PKK cadres in Benteng Village, Ciamis District, Ciamis Regency. There were 75 people who participated in the counseling. The method used in this community service is checking blood pressure which is assisted by students of the nursing study program. Counseling and lectures were carried out through the delivery of material related to the understanding of the COVID-19 disease, explanations of the COVID-19 vaccine and the view of vaccines according to Islamic law. The resource persons came from lecturers of Community Nursing courses in the Bachelor Nursing Study Program of STIKes Muhammadiyah Ciamis. The last activity was a discussion and question and answer about the Covid-19 disease carried out after the counseling.

Table 1. Implementation method

\begin{tabular}{|c|c|c|c|}
\hline \multirow{2}{*}{ No } & \multicolumn{2}{|r|}{ Method } & \multirow{2}{*}{ Success Indicator } \\
\hline & Phase & Description & \\
\hline 1. & Planning & $\begin{array}{l}\text { TEAM formation and } \\
\text { debriefing }\end{array}$ & Successfully formed TEAM \\
\hline 2. & Preparation & $\begin{array}{l}>\quad \text { Formulation } \\
\text { objectives } \\
>\quad \text { of } \\
\text { stakeholders } \\
>\quad \text { Needs collection and } \\
\text { analysis } \\
>\quad \text { Prioritization } \\
\text { problem solutions }\end{array}$ & $\begin{array}{l}\text { Formulation of objectives, } \\
\text { identification of stakeholders, } \\
\text { collection of needs analysis, } \\
\text { obtaining of priority problem } \\
\text { solutions }\end{array}$ \\
\hline \multirow[t]{4}{*}{3.} & \multicolumn{2}{|l|}{ Implementation } & \\
\hline & Consultati & $\begin{array}{l}\text { Conducting consultations at } \\
\text { the village hall }\end{array}$ & $\begin{array}{l}\text { There is support from local } \\
\text { community leaders }\end{array}$ \\
\hline & $\begin{array}{ll}\text { b. } & \text { Counselin } \\
\text { g } & \end{array}$ & $\begin{array}{l}\text { Conducting training programs } \\
\text { for partners }\end{array}$ & $\begin{array}{l}\text { Partners want to take part in the } \\
\text { counseling held }\end{array}$ \\
\hline & Guidance & $\begin{array}{l}\text { Assist with program } \\
\text { application }\end{array}$ & $\begin{array}{l}\text { Assistance in implementing the } \\
\text { program was carried out well }\end{array}$ \\
\hline 4. & Evaluation & $\begin{array}{l}\text { Assess the level of success } \\
\text { carried out }\end{array}$ & $\begin{array}{l}\text { The program is well } \\
\text { implemented }\end{array}$ \\
\hline
\end{tabular}

The description of the stages of program implementation are as follows:

1. Planning

The planning stage is carried out by forming and debriefing a service team consisting of 8 people and then compiling a proposal which is then submitted.

2. Preparation 
The preparation stage was carried out for one week, namely in the form of making an agreement with local community leaders and the community in the Benteng Village, Ciamis sub-district, Ciamis district, formulating goals, identifying stakeholders, collecting and analyzing needs, and determining problem solutions priorities.

3. Implementation

a. Consultation

The consultation phase includes licensing for the implementation of activity programs that aim to facilitate counseling related to public perceptions of the Covid-19 vaccine in Benteng Village, Ciamis District, Ciamis Regency. An indicator of the success of this stage is the support and participation of local partners for the smooth implementation of the extension.

b. Counseling

This stage includes training for local partners related to improving health through counseling public perceptions of the covid-19 vaccine with indicators of the success of this stage, which can be seen from the knowledge and willingness of the community to receive the covid-19 vaccine. The counseling that will be given to the community includes:

1) Health education related to health problems that can be controlled with the willingness of the community to be vaccinated and increase public knowledge about the importance of the covid-19 vaccine.

2) Collaborating with the Covid-19 Task Force and the Ciamis District Health Office to provide counseling to partners in the Benteng Village Environment regarding public perceptions of receiving the Covid-19 vaccine.

c. Guidance

The mentoring phase includes monitoring public perceptions of the receipt of the COVID19 vaccine by involving partners and the entire local community aimed at coordinating the success of community perception facilitation activities on receiving the COVID-19 vaccine, to achieve indicators of success through the knowledge and willingness of the community to receive the COVID-19 vaccine. 19.

4. Evaluation

The evaluation stage is carried out to assess the level of success carried out in the mentoring and counseling program on public perceptions of the acceptance of the COVID-19 vaccine with indicators of the success of the program being well implemented.

\section{RESULT AND DISCUSSION}

This community service activity was attended by 75 elderly people from Benteng Village on February 20, 2021. Health counseling activities about the covid-19 vaccine according to the Islamic view contain information on vaccine programs, safety, halalness and the effectiveness of the covid-19 vaccine for community members in order to form herd immunity so that the pandemic ends soon. This outreach activity was carried out at the Baiturohman Mosque, Bangunsari Environment, Ciamis Village, Ciamis District, Ciamis Regency. This service activity is divided into two stages as follows:

1. The process of delivering material using the lecture method

The second stage is to explain the material by implementing the lecture method. At this stage the elderly are given an explanation of material about hypertension including: understanding, causal factors, signs and symptoms, complications and how to prevent them.

2. Question and answer discussion activities about the material that has been delivered At this stage apply the method of discussion (question and answer). Elderly discuss about the counseling material that has been explained. For the elderly who do not understand, the elderly are allowed to ask questions. Furthermore, at the end of the elderly activity, several evaluations related to the material that have been discussed are given.

The success of health education about the covid-19 vaccine aims to increase public knowledge about the covid-19 vaccine and motivate people to be willing to be vaccinated to create herd 
immunity (Chetty et al., 2020). The motivation of the community members can be seen from their enthusiasm and enthusiasm in counseling, always asking questions regarding the covid-19 vaccine. The community is punctual at the time of the counseling event (Setiawan, Roslianti, \& Firmansyah, 2020). In addition, the community also plays an active role in carrying out the discussion process, they do not feel shy in asking questions if there are counseling materials that are not clear and difficult to understand. they are also active in answering questions about the material that has been delivered by the facilitator (Firmansyah, Setiawan, \& Ariyanto, 2021). This outreach activity about the covid-19 vaccine helps the community overcome their ignorance about the effectiveness of the covid-19 vaccine. Most of the elderly have a positive attitude towards the recommendation of the vaccination program

\section{CONCLUSION}

The Covid-19 Vaccine health counseling activity at the Baiturrohman Mosque, Bangunsari neighborhood, Benteng Village, Ciamis District, Ciamis Regency, it can increase public knowledge about the Covid-19 vaccine, according to an Islamic view, containing information on vaccine programs, safety, halalness and the effectiveness of the Covid-19 vaccine for the community. in order to form herd immunity so that the pandemic ends soon. The success of health education can be seen from the enthusiasm and enthusiasm of the community in participating in counseling activities. In addition, the community is also active in conducting questions and answers with companions and discussing the Covid-19 vaccine from an Islamic point of view. The implementation of this service activity was carried out as expected, namely the smooth process of education and discussion without any significant obstacles. Accordingly, there is a need for socialization from the local health office that can be carried out during the recitation schedule as an effort to accelerate the realization of herd immunity so that the pandemic can end soon.

\section{ACKNOWLEDGMENT}

Thank you to LPPM STIKes Muhammadiyah Ciamis who have funded this community service activity and also thanks to the cadres of the Bangunsari community health post who helped make this service activity a success.

\section{REFERENCES}

Chetty, R., Friedman, J. N., Hendren, N., \& Stepner, M. (2020). How Did COVID-19 and Stabilization Policies Affect Spending and Employment? A New Real-Time Economic Tracker Based on Private Sector Data. National Employment Report, 1(1), 1-84.

Firmansyah, A., Setiawan, H., \& Ariyanto, H. (2021). Studi Kasus Implementasi Evidence-Based Nursing: Water Tepid Sponge Bath Untuk Menurunkan Demam Pasien Tifoid. Viva Medika: Jurnal Kesehatan, Kebidanan Dan Keperawatan, 14(2), 174-181.

Firmansyah, A., Setiawan, H., Wibowo, D. A., Rohita, T., \& Umami, A. (2021). Virtual Reality (VR) Media Distraction Relieve Anxiety Level of the Children During Circumcision. In 1st Paris Van Java International Seminar on Health, Economics, Social Science and Humanities (PVJ-ISHESSH 2020) (pp. 611-614). Atlantis Press.

Haleem, A., Javaid, M., \& Vaishya, R. (2020). Effects of COVID-19 pandemic in daily life. Current Medicine Research and Practice, (April), 10-12. https://doi.org/10.1016/j.cmrp.2020.03.011

Hidayat, S. (2021). Vaksinasi Demi Tujuan Syariah. In SCC Pusat. SCC Pusat.

Nishiura, H., Linton, N. M., \& Akhmetzhanov, A. R. (2020). Serial interval of novel coronavirus (COVID-19) infections. International Journal of Infectious Diseases, 93, 284-286. https://doi.org/10.1016/j.ijid.2020.02.060

Setiawan, H., Khairunnisa, R. N., \& Oktavia, W. (2021). Handwashing Health Education to Prevent Covid-19 Transmission in SMP Inspirasi. Abdimas UMTAS, 4(1), 428-432.

Setiawan, H., Roslianti, E., \& Firmansyah, A. (2020). Theory Development of Genetic Counseling 
among Patient with Genetic Diseases. International Journal of Nursing Science and Health Services, 3(6), 709-715. https://doi.org/http://doi.org.10.35654/ijnhs.v3i6.350 Abstract.

Srinayanti, Y., Malik, A. A., \& Sandi, Y. D. L. (2021). Cold Compress Therapy Against Muscle Stiffness in Patients with Hypokalemia. Genius Journal, 2(1), 16-21.

Suppawittaya, P., Yiemphat, P., \& Yasri, P. (2020). Effects of Social Distancing, Self-Quarantine and Self-Isolation during the COVID-19 Pandemic on People's Well -Being, and How to Cope with It. International Journal of Science and Healthcare Research, 5(June), 12-20.

Wilder-Smith, A., \& Freedman, D. O. (2020). Isolation, quarantine, social distancing and community containment: Pivotal role for old-style public health measures in the novel coronavirus (2019-nCoV) outbreak. Journal of Travel Medicine, 27(2), 1-4. https://doi.org/10.1093/jtm/taaa020 